\title{
Ethnologies
}

\section{The Selection of the Practice of Ice Canoeing on the St. Lawrence River Birth of a Nomination}

\section{Bernard Genest}

Volume 36, numéro 1-2, 2014

Patrimoine culturel immatériel

Intangible Cultural Heritage

URI : https://id.erudit.org/iderudit/1037609ar

DOI : https://doi.org/10.7202/1037609ar

Aller au sommaire du numéro

Éditeur(s)

Association Canadienne d'Ethnologie et de Folklore

ISSN

1481-5974 (imprimé)

1708-0401 (numérique)

Découvrir la revue

Citer cet article

Genest, B. (2014). The Selection of the Practice of Ice Canoeing on the St Lawrence River: Birth of a Nomination. Ethnologies, 36(1-2), 259-277.

https://doi.org/10.7202/1037609ar

\section{Résumé de l'article}

Cet article a pour finalité de décrire précisément de quelle façon et en quelles circonstances la Société d'ethnologie du Québec en est venue à demander au Ministère de la Culture de la province de reconnaître la pratique du canot à glace. En fait, cette pratique figurait en seconde position sur la liste du registre du patrimoine culturel immatériel du Québec depuis sa création en 2012. L'auteur insiste sur le fait que ce processus n'est pas aussi simple qu'on pourrait le penser, et qu'il est fort heureux que la façon dont le formule la Loi sur le patrimoine culturel du Québec, votée en 2012, ne soit pas anodine. Elle implique que si le Ministère confère un statut à un élément du patrimoine immatériel, pour en valoriser la connaissance, la protection, la mise en valeur et la transmission, cela doit se faire dans l'intérêt public. 


\title{
The Selection of the Practice of Ice Canoeing on THE St. LAWRENCE River \\ Birth of a Nomination
}

\author{
Bernard Genest \\ Société québécoise d'ethnologie
}

\section{The Proclamation of February 9, 2014}

On February 9, 2014, the minister for Culture and Communications in Quebec (MCC), Maka Kotto, announced the selection of the practice of ice canoeing on the Saint Lawrence River as part of the intangible heritage under the Cultural Heritage Act. On the occasion of this proclamation which took place at the site and on the very day of the Carnival race, the president of the Quebec Carnival, Denis Simard, signaled his delight with this heritage designation and hastened to inform the press that he was looking ahead even further by making the announcement that the next step for his organization would be approaching the Canadian government to make an official request with UNESCO (Auger, 2014).

It is, however, worth mentioning that it is not the Quebec Carnival but the Quebec Society of Ethnology (QSE) which documented, prepared and made the nomination to the MCC on February 5, 2013. It is true, of course, that the credit goes to the Québec Carnival for the fact that the practice has reached the $20^{\text {th }}$ century and has come to us with such enthusiasm. Since 1955, in fact, the Québec Carnival has made the ice canoe race a part of its program and has declared it one of the main activities The long process which led the minister of Culture to recognize the practice as part of Quebecers' intangible heritage remains, nonetheless, a QSE initiative.

Likewise, since it is part of the strategic planning of the $\mathrm{QSE}^{1}$ to bring the Government of Canada to have ice canoeing included on the representative List of UNESCO, it should be known that such a designation

1. A goal now shared with the Quebec Carnival. 
can only be made under certain conditions. One of these conditions stipulates that the nominating country be a signatory to the Convention for the Safeguarding of the Intangible Cultural Heritage, something that Canada has as yet not become.

The purpose of this article is precisely to outline in what manner and circumstances the QSE came to make the request with the ministry for recognition of the practice as well as the instruments used and the basis for the development of its case. It should be known that the process is not as simple as might be assumed, and it is fortunate that the designation in terms of the Cultural Heritage Act is not a trivial measure. It involves the minister's giving status to a part of the intangible heritage of which knowledge, safeguarding, promotion or transferral is in the public interest. As for the possibility of gaining recognition of a practice as the intangible heritage of humanity, it easy to guess that a single nomination is not enough.

\section{A journey in sereval stages}

The mission

In 2006, when the Ministry of Culture began the process of developing a new legislative framework for the protection of heritage, one which would take into account the widening of the concept in terms of new paradigms. Jean Simard, then president of the QSE, and I, as head of ethnological heritage for the Heritage Branch, were sent on mission to Belgium to document the experience of that country in the management of its intangible cultural heritage. ${ }^{2}$ The Belgian French-speaking community is, in fact, the first western government to adopt a legislative instrument for the protection of its intangible cultural assets. ${ }^{3}$ Our destination was all the more relevant since Belgium had obtained from UNESCO, in 2003 and 2005, recognition of two expressions of popular culture as Masterpieces of the Oral and Intangible Heritage of Humanity: the Carnival of Binche and, in cooperation with France, an ensemble of folklore celebrations featuring Processional Giant and Dragons. ${ }^{4}$

2. For those who wish more information, I've written of this mission in the journal of the Quebec Society of Ethnology: See Genest (2007).

3. The "Decree on movable cultural property and intangible heritage of the French Community" in 2002.

4. Since that time, Belgium has received acceptance for several other events of the list of the intangible cultural heritage of humanity, namely the Holy Blood procession in Bruges in 2009, in 2010 the Carnival of Alost, falconry, a living human heritage item, the Houtern Jaarmarkt, an annual winter fair and animal 
From the outset, our hosts ${ }^{5}$ had planned to have us experience a stay at Binche during the Carnival. We were first taken to the Grand-Place for an introduction to the very heart and soul of the festival which reaches its summit during the Fat days. Although the high point of the event lasts only three days, an observer quickly understands that these days are the culmination of preparatory work and rehearsals which involve the population for much of the year: craftspeople, musicians, Gilles - the symbolic character of the festival - and his supporters. In fact, these celebrations are the most visible part of activities which spread out over the whole year. At that point, the Carnival seemed to us to be a prime example of a tradition handed down from generation to generation, shared by the entire community (in the most common understanding of people who share a set of values, in this case, the citizens of Binche), brought up to date and renewed by its players. The event created a bridge between past and present, between tradition and modernity, contributing at the same time to the maintenance of an identity shaped by centuries of history.

Of course, Simard and I were already familiar with the concept of intangible heritage. Jean Simard, a professor of ethnology à Laval University, had directed several studies dealing especially with the intangible heritage of religious communities. ${ }^{6}$ As ethnological head of the Heritage Branch, I myself had participated in working groups in the course of projects on politics, directed studies on the question and led a mission to the United States in connection with the issue of traditional arts and intangible

market in Hautern Saint Liévin, the Krakelingen and Tonnekensbrand fire and bread festival from late winter to Grammont, the Louvain ritual of age classes in 2011 and the Marches of the Entre-Sambre-et-Meuse in 2012.

5. Jean-Pierre Ducastel, president of the High Council of the French Community and representative for Belgium at UNESCO, Françoise Lempereur of the University of Liège, member of the High Council of the French Community, Christel Deliège, member for the Carnival organization, city of Binche, Annick Vilain, cabinet attachée to Fadila Laanan, minister of Culture for the French Community of Belgium in Brussels, Baron Robert Tolet, president of the Royal Commission for monuments, sites excavations, Walloon Region, Liège.

6. Beginning in 1988, in a research report («Expériences étrangères et stratégies nouvelles pour le patrimoine ethnologique produced for the Ministry of Cultural Affairs (today the MCC), Jean Simard introduced the idea of artefacts and mentifacts, another name for tangible and intangible heritage elements. In the years following, he directed several of his research projects in religious heritage in terms of the idea of the intangible. Among these can be mentioned "The intangible heritage of the Augustines of Quebec's Hôtel-Dieu" (now PIA), a report submitted to the Archives of Laval University (documents under the direction of Jean Simard) as well as to the Museum of the Augustines of l'Hôtel-Dieu de Québec and Simard (1999). 
heritage. ${ }^{7}$ On many occasions we had presented our thinking regarding the importance of the intangible in the heritage system. Furthermore, the QSE was a partner in the project to inventory the ethnological resources of intangible heritage (IREPI) developed by the Canada Research Chair in Ethnological Heritage at Laval University under the leadership of Professor Laurier Turgeon in concert with the MCCCF, ${ }^{8}$ le $\mathrm{MAM}^{9}$ and the Quebec Museum of Popular Culture. The Belgian experience reaffirmed our positions and led us to reflect on the possibility, following the Belgian model, of having one the most significant of our traditions recognized as part of Quebec's intangible heritage. It should be pointed out that at that moment, the Cultural Heritage Act was as yet only a bill and the idea of getting the Government of Canada to bring a nomination to UNESCO for the listing of an event representative of traditional Quebec culture among the Masterpieces of the Oral and Intangible Heritage of Humanity remained a far-off and still vague goal.

\section{Something comparable?}

After returning from our mission, doing a fast inventory of our traditions, we asked ourselves whether, among these, some could be compared with the Carnival of Binche. In discussion with our colleagues, several traditions came to the fore, among them the Quebec Carnival, the Mi-Carême (Mid-Lent) on l'île aux Coudres, at Natashquan, in the archipelago of l'Isle-aux-Grues and on the Magdalen Islands; fishing for tommy-cod at Sainte-Anne-de-la-Pérade, the pilgrimages to Ste-Anne de Beaupré, the arrow sash of Lanaudière and the syrup production of the Appalachian region. At length, the events connected with Carnival seemed to us especially indicative of Quebec cultural specificity, given the importance of winter in our lives. All the Québec Carnival activities do not have, however, the same historical roots as the practice of ice canoe 7. In 1987, I had been the project officer in Washington DC to study government aid for the promotion with the Smithsonian Institute in the United States of the Intangible Heritage of the National Folk Festival, the National Endowment for the Arts and the National Council for the Traditional Arts. That same year, as a member of a study group formed to prepare a policy statement regarding cultural politics, I had proposed an approach which divided the concept of ethnological heritage into two fundamental components, the tangible and the intangible. (See Genest, 1988). See also Sophie-Laurence Lamontagne (1994), and Genest and Lapointe (2004).

8. At the time, ministère de la Culture, des Communications et de la Condition féminine, today ministère de la Culture et des Communications (MCC).

9. Today ministère des Affaires municipales, des Régions et de l'Occupation du territoire (MAMROT). 
navigation on the Saint Lawrence in winter. For this reason, we felt compelled to choose, among them all, this one which seemed, a priori, the most authentic.

We began with the hypothesis that, from a historical and systemic point of view, this practice was one of the oldest winter traditions which have come down to us. Deeply anchored in Quebec culture and in its historical and geographic reality, this tradition has developed through the ages without undergoing folklorization or revivalism. However, a demonstration was still required. Thus it was, in 2008, that a research project was presented to the MCCCF which supported its recording in the cultural agreement with the city of Quebec.

\section{The study}

The research project fit exactly with the mission to safeguard and promote the QSE's ethnological heritage. The Society has, in fact, as its field of investigation, culture in its various representations, both tangible and intangible. The objective was to document a practice many traces of which we can find in historical accounts, literature and the arts, a practice still living in the present day. It was a matter too of promoting recognition of this and developing a research protocol which could ultimately be applied to other such intangible manifestations. It should be remembered that at that time there was a series of instruments for documenting movable and unmovable assets, but no such thing for the intangible. ${ }^{10}$ UNESCO had, however, developed in the course of its program for the recognition of Masterpieces of the Oral and Intangible Heritage of Humanity (UNESCO, 1998), a presentation guide for nominations which would, obviously, provide much inspiration for us.

It should be said that, at the outset, the project was to deal with the whole of Quebec province, but the city of Québec demanded that the area of study focus rather on its territory, in particular, between Québec and Lévis, where the practice was centred. The mandate was given to ethnologist Richard Lavoie ${ }^{11}$ under the direction of a scientific committee made up of representatives from the Ministry, the city of Québec and the QSE.

10 Except for the work by Sophie-Laurence Lamontagne, already quoted, and the computer tools developed by Laval University and its partners, the MCCCF and the QSE, in the framework of the project to inventory the ethnological resources of intangible heritage (IREPI).

11. Richard Lavoie already had a good knowledge of the subject from having carried out oral investigations with canoeists, produced research reports and published articles in journals (Lavoie, 2001; Lavoie and Drolet 1989; 1990). 
The context (2008)

The definition of intangible heritage

Long faced with problems of definition and terminology, specialists taking part in UNESCO's international conferences finally came, at the start of the 1990s, to a consensus on the designation of an entity which, to that point, had been quite vague. It was, in fact, during an international consultation held in Paris in June 1993 that the expression intangible heritage was adopted, settling the endless debates about terminology. It was not, however, until 2003, at the adoption of the Convention for the Safeguarding of the Intangible Cultural Heritage ${ }^{12}$ that the definition issue would be finalized. Following is the conclusion:

The "intangible cultural heritage" means the practices, representations, expressions, knowledge, skills - as well as the instruments, objects, artefacts and cultural spaces associated therewith - that communities, groups and, in some cases, individuals recognize as part of their cultural heritage. This intangible cultural heritage, transmitted from generation to generation, is constantly recreated by communities and groups in response to their environment, their interaction with nature and their history, and provides them with a sense of identity and continuity, thus promoting respect for cultural diversity and human creativity. For the purposes of this Convention, consideration will be given solely to such intangible cultural heritage as is compatible with existing international human rights instruments, as well as with the requirements of mutual respect among communities, groups and individuals, and of sustainable development.

In 2007, the Quebec government's Green Paper on cultural heritage, Un regard neuf sur le patrimoine (Ministère de la Culture, des Communications et de la Condition féminine, 2007) reproduced the text of this definition, ${ }^{13}$ and with the exception of the last section dealing with human rights, with mutual respect between communities, groups and individuals and with sustainable development, these principles and considerations were taken for granted in Quebec. ${ }^{14}$ In the spirit of the Green Paper, heritage was understood as a system whose various components, tangible, intangible and natural were brought together by an organic relational link.

12. At the General Conference of October 17, 2003.

13. In the second part of the document, in the section dealing with widening the field of application of the Act on cultural assets.

14. The Act on sustainable development adopted in 2006, for example, brought in new rules and obligations for the entire Public Administration. 
At the moment of carrying out the study, the UNESCO definition of intangible heritage, taken up again in the Green Paper, would serve as a point of reference. Sticking to it ensured that we would respect the general consensus surrounding the obligation to consider heritage according to a global approach and as a "polysemic, cultural, identifying, historical, architectural, economic, environmental and urban system [...],"in short to possess a holistic vision of the concept.

Understood in this way, the intangible was not separated from the milieu nor from the physical and environmental framework it originated from; it fit in, on the other hand, with a group of organized elements. Thus, the importance of setting the practice within its various contexts. It seemed to us that the approach should be both historical and ethnological, that is to say, should follow the development of the practice in time and space based on the data recorded in the archival documents and the accounts of chroniclers, and then proceed somewhat in reverse, by documenting its dynamism based on testimonies given by its actors: former canoeists and young practitioners.

\section{Analytical criteria}

Moreover, in the course of its program of Proclamation of the Masterpieces of the Oral and Intangible Heritage of Humanity (since replaced by the representative List), UNESCO was proposing a Presentation Guide including a list of criteria likely to facilitate the analysis of the heritage potential of an event. These criteria are outlined as follows:

First is the extraordinary value of the performance, this value which distills from the combination of several other criteria:

The rooting of the tradition in the cultural history of the community from which it comes

Its identity-forming nature for the cultural community in question

Excellence in the application of a skill and the technical qualities displayed

The creativity aspect as a source of inspiration and intercultural exchanges

Its specificity or its value as a unique testimony

Its updating to present time 
Its symbolic scope

Its iconic and popular character

And the potential risk of its deterioration or its disappearance.

Although some of these criteria have since come under discussion and been further qualified, they are, nevertheless, still today indicative of the heritage potential in a practice. These criteria acted as parameters for the study.

The research report (2010)

In 2010, The QSE submitted its report to the city of Québec and the Ministry: "The crossing of the Saint Lawrence River by ice canoe at Québec." The report is organized around three main chapters: The development through history of ice canoeing $\left(17^{\text {th }}\right.$ and $18^{\text {th }}$ centuries); the golden age of winter transport by canoe (19 ${ }^{\text {th }}$ century); the use of this ancient mode of transport as a sporting event ( $20^{\text {th }}$ century). There are 184 pages of text along with a rich iconography, varied and on target. After the analysis of its content, the authors clearly showed that the beginning hypothesis was proven true: the phenomenon of navigating in an ice canoe in the winter in the region of Québec City constituted, in fact, a unique and extraordinary example of heritage, one to be protected, promoted and showcased. To respond to the demands of the city of Québec, the study had dealt essentially with the immediate region around Québec City and especially that part of the river between Québec and Lévis. This space forms a sort of triangle located between Pier 18 at the Port of Québec, the Queen's Pier (Coast Guard base) and the Paquet Pier in Lévis, showplace for the famous Carnival race. This space has always been one of the focal points of the event according to the testimonies of missionaries and travelers of the $17^{\text {th }}$ and $18^{\text {th }}$ centuries, along with those of chroniclers, historians and novelists of the $19^{\text {th }}$ and $20^{\text {th }}$ centuries. The path traveled by couriers and ferries (mariners) was about the same as that followed by today's canoeists during the Carnival race. The route has changed little and the conditions are much the same except for the boats and equipment which have developed a great deal. The same effort is required and it is just as necessary to master the movement of the ice floes and the unforeseeable whims of nature as it was in the past. 
Among the recommendations accompanying the report, various means were proposed to raise public awareness to the importance of ice canoeing as a legacy from Quebecers' cultural heritage. Among those methods, ${ }^{15}$ the QSE concentrated on providing information through a mass publication. This publication also was intended to furnish a working instrument both easy to use and attractive to municipal and government managers, to Carnival organizers and to Québec Port authorities, as well as historians, ethnologists and other heritage agents whose mission is to promote the territory's cultural resources.

At the same time, the publication was also meant to help expand the subject by locating it in a less limited space-time context than the study sought by the city of Québec and the Ministry. Produced without financial support (other than participation on the part of the publisher), there appeared after two years a 236-page revised and expanded edition lavishly illustrated: Ice canoe navigation, a feature of the intangible heritage (Lavoie, 2012). The book would serve as a reference text for the preparation of the status request presented to the Ministry according to the provisions of the new Cultural Heritage Act. It contained the argument on which the request was based.

\section{A practice enshrined in history}

The practice enters fully into the history of Quebec. Its occurrence is rooted in the geography of the place and in its birth since the aboriginal people moved about in fragile craft even in winter, despite the risks involved. Throughout the $17^{\text {th }}$ and $18^{\text {th }}$ centuries, we find a good many witnesses among writers and travelers, from the time of Samuel de Champlain in 1609, followed by Jesuits Paul Le Jeune and François-Xavier de Charlevoix, who report seeing such expeditions and, in some cases, taking part in them.

In the $19^{\text {th }}$ century and at the outset of the $20^{\text {th }}$, historians and writers, such as Philippe Aubert de Gaspé, Louis Fréchette, Napoléon Legendre, Joseph-Edmond Roy and Pierre-Georges Roy make mention in their writings of transporting people, mail and merchandise through the ice on the Saint Lawrence. They cite epic, sometimes tragic, crossings which

15. Many of these activities have actually been carried out over the years that followed, mainly by Richard Lavoie, author of the report. In May 2012, the Company deferred to seven former emeritus boaters a certificate of recognition on the occasion of its Annual General Meeting held at the Musée maritime du Québec in L'Islet-sur-Mer 
gave birth to local folklore like the legend of La Tête à Pitre. They tell of customs and songs that herald the prowess of these navigators who braved the elements to carry safely to port passengers and goods. The $19^{\text {th }}$ century was also the period of couriers, a trade passed on from father to son in families that have become legendary, such as the Barons, the Barras, the Bégins, the Chabots, the Labadies, the Ladrières and the Vallerands who have left their mark in our memory but also in place names in Québec City and more so in Lévis.

With the arrival of steamships, the courier trade between the two cities fell into decline, but the practice was not altogether abandoned. It did not disappear from the habits and customs of Quebecers. In Québec City, the practice would give birth to a sport, namely the ice canoe race. Introduced in 1894 at the first Québec Winter Carnival, ice canoe racing reappeared sporadically in the 1930s and finally, in 1955, became a regular part of the Québec Carnival festivities, when the winter celebration turned into a veritable institution. Nowadays, the event remains one of the most publicized parts of the Carnival and other races are held within the Quebec Ice Canoe Circuit.

But make no mistake about it. Although the sporting event, refreshed and supported by the Quebec Carnival, has always been the focal point of the general public and the media, the transport of goods and passengers was carried on elsewhere until relatively recently. Still today, former canoeists give witness to this. For island dwellers, canoe crossings were second nature since people could then travel from their location to terra firma. In several places, on l'île aux Coudres, l'île au Canot, l'île aux Grues, l'île Verte and elsewhere in the Gulf, these crossings were an almost daily activity during the winter.

\section{A strongly identity-related practice}

If there is an activity which Quebecers immediately recognize as part of their cultural heritage, it is ice canoeing. The river, as everyone knows, has always played a significant role in the social and economic life of Quebecers. Quebec's development has been conditioned by the possibility of traveling as much in winter as in summer. The Saint Lawrence has long been a veritable highway which makes possible the passage of people and goods and their establishment along its banks. Already before the arrival of Europeans, the aboriginals moved about on the river and its tributaries in dugouts or in canoes. Of course, navigation on waterways is not peculiar 
to Quebec, but winter travel through ice floes is a particularity of northern countries. There is no doubt that the tradition is the fruit of intercultural exchanges between the first settlers and the natives. It is a strong symbol of the concept of nordicity developed by the geographer Louis-Edmond Hamelin of Laval University at the outset of the 1970 s, ${ }^{16}$ a concept which influenced the city of Québec to claim the title as "world nordicity capital" at the 1999 World Nordicity Summit. One of the determining factors was, in fact, the ability of people in northern countries to adapt to the climate and the environmental conditions of the territories they inhabit. Is there a clearer symbol of this capacity than the story of ice canoeing in the middle of the Saint Lawrence? Reenergized and maintained over 400 years, this tradition testifies to this knack of Quebecers to occupy and develop the land despite the harsh climate and often uninviting environment. Every crossing, today as in the past, speaks of this victory over the elements and of the moral and cultural values inherent in the practice.

This practice is also representative of Quebecers' distinctiveness in the sense that it represents testimony to a maritime tradition that belongs uniquely to the Saint Lawrence River. Now and then, canoeing through ice floes has been practised elsewhere in Canada $^{17}$ (in the Magdalen Islands, ${ }^{18}$ on Prince Edward Island, on the coast of new Brunswick in Northumberland Strait), but ultimately has only survived in the Saint Lawrence Estuary.

\section{Intermingling and creative genius}

The aboriginals traveled the river in winter using frail craft always in danger of breaking every time they too forcefully ran up against the blocks of ice floating back and forth with the tides. Tales of voyageurs make mention of these dangerous trips which often came to a sudden end. Even so, the skills of settlers combined with the experience and practical knowledge of the native people enabled the rapid improvement of the boats and the development of ingenuity in the art of moving about amid the ice. Monseigneur Savard, in a 1949 article published in Les Archives de Folklore, provides a good description of this proficiency:

The winter boatmaster possesses a treasure trove of knowledge of the movement and the resistance of the ice floes. He gives names to these, calling them, for example, "l'arrêté," when they briefly come to a stop

16. In 1976, he proposed a system of ten indicators that are interconnected. He called these "polar values," intended to measure the nordicity of various points north of the $50^{\text {th }}$ parallel.

17. And perhaps elsewhere in the world as affirmed by Pierre Lahoud (2013).

18. With the famous canotte of the islands. See Chiasson (1981: 107). 
in the slack; "drivant," when they are on the move; "redoublé," when they overlap one on the other; "frasil," when they adopt the consistency of thick 'broth.' He judges by their colour, grey, green or black, if they are "pourries," in "chandelles" or pierced with 'warm holes.' Even their sound, dry or dull, enables him to guess the coldness or mildness of the temperature. This means he has his eyes open for the smallest signs, he knows how, in an impasse, to avoid the dangerous ice, to jump as needed on those floes that will "carry"; and to navigate through all the openings, 'cuts or bleeds' of clear water which the current opens for him.

Strategy varies according to the condition of the channel. In frasil, you must 'stir' all together, to the right, to the left and "lean" on the oar. This kind of roll, eventually very tiring, produces a swell that loosens the pressure of the jam. However, as soon as an ice floe is wide and solid enough, you haul the boat onto it. The boatmen, with one hand on the hull and the rope over their shoulder, cross the sea ice at a run, at the risk of having to immediately board again afterward, to "slip back in" without problems to take again their place, at the rowing bench.

These various movements are not free of risks; and the lookouts on the island (l'Ile aux Coudres) never lose sight of the movement of the boats. However, though some crossings are long and rough; though a soaking often occurs in the icy water; though the canoes may drift and do sometimes... by the rescue services, thanks to God, serious accidents are rare. (Savard 1949: 15)

Today's canoeists form a part of this long chain of knowledge and knowhow. They are the links and, in this way, they are responsible for not only passing on this knowledge but also for improving and fine-tuning it. They do this so well that we can almost label it as being a new kind of navigation science, a science that has effects in several sectors of maritime life. The example could be given of the Lachances of Montmagny. Born in a family of canoeists and boatmen which came from l'île au Canot, the Lachances recently found inspiration in the technology of ice canoe building for their creation of an unsinkable rescue craft 17 feet $(5.8 \mathrm{~m})$ in length, the UMA17. What's more, it was thanks to the help of three young canoeists that on January 9, 2012 a young fisher and his dog, who had been carried away by the ice, were saved. This brought forth these words from the eminent ethnologist Jean Simard: "UMA-17 is a happy marriage of tradition and innovation, a good example of cultural heritage that is always adapting"(in Lavoie 2013).

Excellence, in this case, is measured in terms of knowledge, in the sense of scientific knowledge, like the skill resulting from experience and empirical observations. 
A living and dynamic practice

The power of the testimony is as pervasive today as in the past. It's a matter of a living and dynamic practice which is renewed each year, in its present form, in several places along the Saint Lawrence. The focal point of the activities remains, as it was in the golden age of canoe transportation, in this legendary space separating Québec City and Lévis, the stage for the prestigious Carnival race and the Great Québec Ice Challenge. Now, however, races are also held at Montreal (Montreal Ice Canoe Challenge), on the floes at Portneuf (between Portneuf and Pointe-Platon), in Charlevoix (The Great Casino Crossing of Charlevoix between l'Isle aux Coudres and Saint Joseph de la Rive) and in recent years, at Trois Rivières (although the Trois Rivières Extreme has not been repeated in 2014).

The tradition goes on, thanks to a new generation of canoeists, some of their number coming directly from the old families where it was a necessity, such as the Dufours of l'île aux Coudres or the Lachances of Montmagny. Others, who have been trained by seniors, carry on one of the oldest forms of knowledge transfer, namely from master to apprentice. Former captains, for example, will train youth who have come from other areas.

The practice, formerly reserved for men, ${ }^{19}$ is now open to women. Women's teams have been competing since 1984; they even teach one another. There are also examples of transmission by descent, as with one experienced canoeist, Nathalie Dufour, originally from l'île aux Coudres, whose maternal grandfather was a boatman by trade. After training her own son and instilling in him her passion, Nathalie Dufour also trained young male teams in canoeing. She is a living example of unbroken transmission through contact between generations because, as the granddaughter of a canoeist, she has always been in contact with the world of ice canoeing. Thence also, her interest in competition.

\section{Symbolic and popular}

It was not by chance that canoeists of the past were seen as popular heroes and their feats nourished folklore and inspired poets and novelists. They embodied, and still do, that quality of resilience in their forebears who overcame difficult climatic conditions and the natural barriers of the environment to build the nation. In the 1950s, as if to reclaim their power and courage, the canoeists donned the traditional habitant costume, top coat, arrow sash, red wool toque and plaid shirt.

19. Although during some crossings, island wives do not hesitate to lend a hand to their men to contribute to the common effort. 
Still today, what fascinates and calls forth the admiration, year after year, of crowds by the thousand, who invade the Québec and Lévis piers during Carnival, is the symbolic nature of the event. The activity has always been one of the most publicized of Carnival, this great winter festival. In the 1960s, Radio Canada broadcast the Carnival ice race live on television. At the start of 1990, the well-known program Good Morning America, watched by millions of viewers, aired a special program on the Québec Carnival and the ice race. Nowadays, coverage reaches France, Germany and elsewhere in the world, even Japan. Articles on the subject appear regularly in print and the electronic media. Indeed, the film, De l'eau glacée dans les veines (Ice water in their veins) by Cimon Charest took several awards in documentary film festivals in Quebec and the United States. And after providing inspiration for painters, engravers and sculptors like Eugène Hamel, Cornelius Krieghoff, Charles Huot, Spencer Westmacott, Jean-Julien Bourgault and Jean-Paul Riopelle, the practice remains a source of motivation for artists like painter Tex Lecor or photographer Michel Corboz who use it to create images which are totally captivating and of great beauty. And finally, let us recall that the practice has nourished folklore themes - songs, stories and legends - which have provided fertile soil for many writers, so many testimonies that confirm the importance of this tradition in Quebec culture and the place it holds in popular imagination.

\section{A tradition of unbroken contact}

The practice of ice canoeing has never ceased to find renewal and see development. It has gone from a once mainly utilitarian activity to a sporting event, passing directly from one generation to the next up to the present day. We too often forget that its first function, namely the transport of people and goods, carried on during the greater part of the $20^{\text {th }}$ century. While the courier trade between Québec and Lévis has disappeared with the arrival of ferries at the outset of the $20^{\text {th }}$ century, it was not so on the islands of the Saint Lawrence, there where the ice canoe was a necessity when other roads became impassible or dangerous; in small craft before the river froze or via the ice bridges that formed around the islands and the north and south banks. We think, of course, of the services which boatmen provide for the many islands that dot the lower Saint Lawrence, among them l'île aux Coudres, l'île d'Orléans between Saint-Jean and Saint-Michel-de-Bellechasse, l'île aux Grues and Montmagny, l'île aux Oies and Cap Saint-Ignace and l'île Verte, where "the road that walks becomes the road that slides" to use the expression of Pierre Lahoud in his article in the journal Rabaska (Lahoud, 2013: 140). 
It is not by chance that for years the Lachance family has walked away with first prize at the Québec Carnival race. It is because, of necessity, they trained in their daily lives as soon as the climatic conditions made other means of transport impossible. Nor is it by chance that the members of this family of celebrated canoeists have developed their expertise in the construction of winter canoes. Nor is it a "breach of faith" ${ }^{20}$ with its original function. Quite to the contrary, it has involved adapting to the new contextual environment and finding in it new avenues for use. For this reason, we can affirm that the practice of ice canoeing is a dynamic activity experienced through change and unbroken in its contact with tradition.

Contrary to many other practices which have disappeared and then been revived through the enthusiasm of amateurs or professionals and cultural mediators, the practice of ice canoeing experienced a certain 'cooling off' at the beginning of the $20^{\text {th }}$ century but never disappeared. However, despite its dynamic nature in recent years, the practice remains precarious for several reasons, some, of the natural order like global warming - which was, of course, not the case in 2014 - and others, economic and administrative in nature. Efforts over the last few years to raise its profile and gain recognition for this important tradition in Quebec's cultural, social and economic history have borne fruit, and yet its survival must not be taken for granted. Obviously, its designation as part of intangible heritage in terms of the Cultural Heritage Act gives witness to its importance and will foster its continuity and showcasing.

\section{The request for designation (2013)}

It goes without saying that the object of the request for designation should correspond with the definition of intangible heritage included in chapter 1 (Objects, Definitions and Applications), Article 2 of the Cultural Heritage Act enacted on October 19, 2012. According to the terms of the Act, intangible heritage is defined as follows:

The skills, knowledge, expressions, practices and representations transmitted from generation to generation and constantly recreated in conjunction, where appropriate, with objects and cultural spaces associated therewith, which a community or group recognizes as part of its cultural heritage and whose knowledge, safeguarding, transfer or development is in the public interest.

20. Unfortunately, the formula was used at the proclamation of the practice of ice canoeing on February 9, 2014. 
This definition, although more succinct, is, for the most part, faithful to the spirit of the definition contained in the UNESCO Convention for the Protection of Intangible Heritage, which had served as a frame of reference for the analysis. Consequently, it was relatively easy to adjust the argument in terms of the Minister's expectations, to complete the description of the item for which the designation request was prepared.

This argument responded to the "what," the "who," the "how" and the "how long" of the form prepared to this end. The practice corresponded perfectly with the definition of intangible heritage included in the text of the Act:

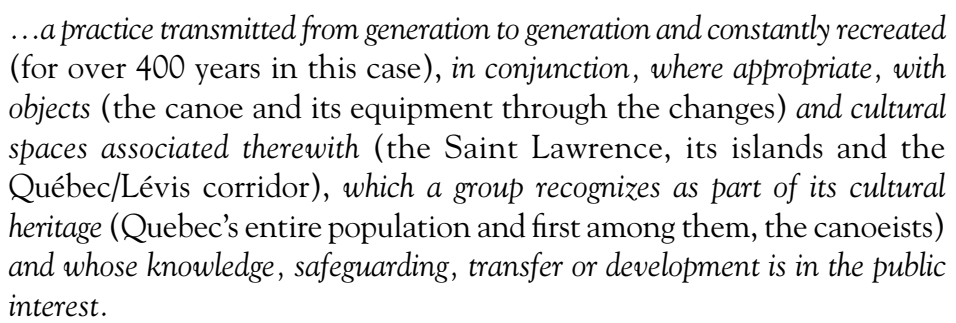

Because it has all the attributes generally associated with intangible heritage - rooting, scope in terms of symbol and identity, uniqueness, specificity, popular character, strength of testimony, excellence of knowledge and skill, transfer from generation to generation, updating to the present day, dynamism - the safeguarding of the tradition is obviously in the public interest. This has been confirmed by the inclusion of the practice of ice canoeing on the Saint Lawrence in the records of cultural heritage of the Government of Quebec.

\section{The final goal: international recognition}

While an essential and important step, the designation of the practice of ice canoeing by the Government of Quebec as a feature of the intangible heritage does not represent the final goal of the QSE. The organization's ultimate goal remains that of international recognition. That being said, the holders of the file are entirely aware of the difficulties ahead and the steps remaining in this process.

On the one hand, the study must be widened to all those places where the practice is carried on, both in Quebec and in the Maritime Provinces. Supported by a grant from the MCC (an amount of $\$ 40,000$ was given to the QSE at the time of the proclamation), all the places of this practice, 
other than those already covered by the 2010 project, will be studied beginning this year, namely Montreal, Trois-Rivières, Portneuf, Cap-Rouge, l'île d'Orléans, la Grosse Île, l'île au Canot, l'île aux Grues, l'île SainteMarguerite, l'île aux Oies, l'île Verte and the Magdalen Islands. In the relatively near future, steps will be taken with the Canadian government to seek needed financing for the follow-up work in other parts of the country where ice canoeing has been practised. In the Maritimes, for example, documents make mention of ice canoes for the transport of passengers and mail between New Brunswick and Nova Scotia. The QSE hopes to develop partnerships to cover these regions.

On the other hand, since Canada has not yet signed the Convention for the Safeguarding of the Intangible Cultural Heritage, we are well aware that only those countries which are signatories can present a nomination for recognition to UNESCO. This does not keep anyone from taking steps with the authorities to get Canada to join the 158 states across the globe which have adhered to the Convention as of November 20, 2013.

Let us remember that, at the moment of beginning the first phase of the study, the Cultural Heritage Act was still only a relatively vague project. When it was proclaimed, the QSE was in possession of instruments for immediate submission of a designation request. The game plan to obtain international recognition is essentially the same. Many changes may occur by the time the study is completed and finalized. Furthermore, there is no doubt that designation by the Quebec government of the practice of ice canoeing as a feature of the intangible heritage, similar to that of the Inuit Gorge (January 28, 2014), together with the support which these designations have aroused on the part of well-known institutions, are new elements which may spur on the Canadian government to sign the Convention. 


\section{References}

Auger, Samuel, 2014, «En canot jusqu'à l'Unesco, Une tradition unique à protéger ", Le Soleil, February 10, 2014. ("Canoeing to UNESCO, A unique tradition to be protected")

Chiasson, Anselme, 1981, Les Îles de la Madeleine. Montmagny: Leméac.

Genest, Bernard, 2007, Le Patrimoine immatériel en Belgique francophone : un modèle pour le Québec, Rabaska, 5 : 47-70.

Genest, Bernard, 1988, « Le patrimoine ethnologique » In Le patrimoine culturel, l'état des lieux. Portraits de patrimoines: 72-86. Québec, MAC, 1988.

Genest, Bernard and Camille Lapointe, 2004, Le patrimoine culturel immatériel, Un capital social et économique. Québec: Gouvernement du Québec, Culture et Communications.

Lahoud, Pierre, 2013, « Naviguer en canot sur le chemin qui glisse » Rabaska, revue d'ethnologie de l'Amérique française, 11: 136-142.

Lamontagne, Sophie-Laurence (under the direction of Bernard Genest), 1994, Le patrimoine immatériel, méthodologie d'inventaire pour les savoirs, les savoir-faire et les porteurs de traditions. Québec: Les Publications du Québec.

Lavoie, Richard, 2013 « La navigation en canot d'hiver en constante évolution » Société Québécoise d'Ethnologie, January 15: http:// ethnologiequebec.org/2013/01/la-navigation-en-canot-dhiver-enconstante-evolution/

Lavoie, Richard, 2012, Naviguer en canot à glace, un patrimoine immatériel (avec la collaboration de Bernard Genest). Québec, Les Éditions GID.

Lavoie, Richard, 2010, La traversée du fleuve Saint-Laurent en canot à glace à Québec. Étude pour la reconnaissance nationale et internationale d'un patrimoine immatériel exceptionnel présentée à la Ville de Québec et au ministère de la Culture, des Communications et de la Condition féminine $\mathrm{du}$ Québec. Introduction and conclusion by Bernard Genest. Québec: SQE.

Lavoie, Richard, 2001, "Du transport au sport : Le canot à glace » ("From transport to sport: The ice canoe"), Cap-aux-Diamants, 64: 29-34.

Lavoie, Richard and Simon Drolet, 1990, "Le canot à glace du transport au sport", L'Escale, 33: 16-19,

Lavoie, Richard and Simon Drolet,1990, "Les drosseuses : dès que la glace cédait sa place”, L'Escale 29: 19-20.

Ministère de la Culture, des Communications et de la Condition féminine, 2007, Un regard neuf sur le patrimoine culturel, Révision de la Loi sur les biens culturels, Document de réflexion. Québec: MCCCF

Savard, Félix-Antoine, 1949, "La traverse d'hiver à l'Ile-aux-Coudres" 
Archives de Folklore, 4: 13-16.

Simard, Jean, 1999, "Le patrimoine immatériel des communautés religieuses," Les Cahiers des dix 53: 251-287

UNESCO, 1998, "Proclamation of the Masterpieces of the Oral and Intangible Heritage of Humanity," Regulation adopted at the $155^{\text {th }}$ session of the Executive Council (Decision 155 EX/3.5.5.). Paris: UNESCO

UNESCO, 2003, Convention for the Safeguarding of the Intangible Cultural Heritage. Paris, UNESCO. 